\title{
CURRENT TRENDS IN POPULATION PROTECTION IN EUROPE AND THEIR RESEARCH SUPPORT IN THE CZECH REPUBLIC
}

In the contribution, on the base of a systematic study of evolution trends in the field of population protection in some European countries, current looks on a wide-spectral approach of this issue were generalized. The contribution deals with: Protection of population as an integrated system, Risks and threats, Mission, Main tasks, Powers, Rescue entities, Management structures, Service model, Education and training, Protective infrastructure, and International co-operation. In connection with the necessity of research support of measures for population protection, the current state in this issue in the Czech Republic was described.

\section{The most important elements in protection of population}

\section{Protection of Population as an Integrated System}

In some countries (including the Czech Republic) a term protection of population has been already introduced (or its introduction is under preparation)into their legal system as a certain "roofing" name for an integrated system. The current framework of protection of population in many European countries can be generally demonstrated by the following scheme:

\begin{tabular}{|c|c|c|c|}
\hline $\begin{array}{l}\text { Kind of } \\
\text { events }\end{array}$ & Daily events & $\begin{array}{l}\text { Disasters and } \\
\text { emergencies }\end{array}$ & Armed conflicts \\
\hline $\begin{array}{l}\text { Field of } \\
\text { activity }\end{array}$ & $\begin{array}{l}\text { Prevention of } \\
\text { damage }\end{array}$ & $\begin{array}{c}\text { Protection against } \\
\text { disasters } \\
\text { (Natural disasters, } \\
\text { industrial } \\
\text { accidents) }\end{array}$ & $\begin{array}{l}\text { Civil protection } \\
\text { (Protection of } \\
\text { population in } \\
\text { wartime) }\end{array}$ \\
\hline Competence & \multicolumn{2}{|c|}{$\begin{array}{c}\text { Self-government, lower level of state } \\
\text { administration }\end{array}$} & State \\
\hline \multirow[t]{2}{*}{$\begin{array}{l}\text { Rescue } \\
\text { entities }\end{array}$} & \multicolumn{3}{|c|}{$\begin{array}{l}\text { Fire fighters } \\
\text { Health rescue work } \\
\text { Auxiliary services }\end{array}$} \\
\hline & & \multicolumn{2}{|l|}{$\begin{array}{l}\text { National forces } \\
\text { Armed forces }\end{array}$} \\
\hline
\end{tabular}

Scheme No.1: Structure of protection of population

In fact, three kinds of events can be distinguished, namely socalled daily events, disasters and emergencies, and armed conflicts. Under the term daily events we understand traffic accidents, railway traffic accidents, plane crashes, construction crashes, explosions and breakdowns of engineering communications and service pipelines, salvage of persons in various situations, etc. This means the events with a small number of health and irrecoverable losses with low material damage and a minimal impact on the infrastructure of a society and the environment. The field of activities in case of daily events can be generally called damage prevention.

Disasters and emergencies include natural and industrial disasters with a great number of health and irrecoverable losses, with large material damages, with massive impact on the infrastructure of a society, life of population and environment. Most of all they represent vast floods, landslides, earthquakes, vast surface fires, snow avalanches, breakdowns of industrial production plants and transportation systems with the escape of gaseous toxicants and radioactive agents. The field of activities in case of disasters and emergencies is generally called protection against disasters.

Armed conflicts can be of a national character (civil or ethnic wars), war conflicts between two sovereign states or a coalition war between two military groups of sovereign states may occur. The field of activities during armed conflicts is called civil protection (defence) in terms of the international humanitarian law within the meaning of Additional Protocols I and II to Geneva Treaties of 1949 on protection of armed conflict victims adopted in Geneva in 1977.

\section{Risks and Threats in a Non-military Field}

New threats and some enduring long-term risks began to appear in relation with the end of cold war.

A permanent threat is represented by states, non-governmental groups, and organisations not respecting the international law and enforcing their interests by war, violence and encroaching on human rights. Ethnic and religious conflicts, economic and social problems and violation of human rights inside the states are the sources for regional crises.

Threat of use of mass destruction weapons cannot be excluded and the range of entities disposing of these weapons or willing to

\footnotetext{
* Petr Linhart

Population Protection Institute - Ministry of Interior, General Directorate of Fire \& Rescue Service of the Czech Republic,

E-mail: petr.linhart@ioolb.izscr.cz
} 
acquire them is still growing. Situations when individuals or nongovernmental entities acquire these weapons are the most dangerous.

Frequent and extraordinary dangerous phenomenon is terrorism and extremism in many regions. Real threat is a possibility of using weapons of mass destruction for duress. The most serious threat for the European security is the situation in South-Eastern Europe, Near East and North Africa.

Regional conflicts and differences in the standard of living are the reasons for political and economic migration. Negative reactions of some groups of inhabitants of target countries against immigrants push these people aside of the society and often throw them to individual or organised criminality.

Communication capabilities that open a space for organised criminality, drug trade and terrorism bring new risks. There exist real threats of subversive activity based on breaking into electronic and information systems and their interference.

Global risk is caused by an uneven development and still growing gap between the standard of living in Euro-Atlantic region and a limited group of other highly developed countries and countries in Southern Hemisphere.

An individual chapter is a negative impact on the environment as a result of anthropogenic activities resulting in natural disasters, climatic changes, a loss of drinking water, epidemics, and a lot of subsequent and accompanying negative events.

Most European countries recognize, consider as serious and get ready for the risks as follows:

- Natural disasters;

- Industrial disasters;

- Damaged environment as a result of anthropogenic activity;

- Failures in provisioning;

- Epidemics;

- Mass migration;

- Organised criminality;

- Terrorism and extremism of all kinds;

- Drug trade;

- Uncontrollable proliferation of mass destruction weapons;

- International conflicts outside Europe as well as in its vicinity (Near East).

Reassessment of a risk at the very end of the last century also resulted in a changed approach to protection of population. This was proved especially by transferring from protection of population against war effects (civil protection, civil defence) to protection against the above-mentioned risks in peacetime. Practical consequence of such changed priorities in protection of population was the revision of respective legislation standards (laws in particular), total dissolution or maximal minimisation of fixed structures intended in case of war, limitation especially of state finances primarily in the material field by devolving of powers from the level of the state to the level of lower administration and self-gov- ernment levels, stopped or very limited building of protective infrastructure and reduced obligatory service (in countries where it had been introduced).

\section{Mission}

In the last quarter of the twentieth century the centre of measures within the framework of protection of population began to move from an armed conflict "segment"(civil protection, civil defence in terms of international humanitarian law) to a "segment" of disasters and emergencies (protection against disasters) in Europe and in the world. These tendencies became concrete especially after a meeting of the European Union ministers held in 1986 which laid the bases for a common policy of the European Union in the field of civil protection (this name was adopted for this activity in the E.U.), and after the adoption of the Roman Treaty by the NATO states in 1991 where the priorities were changed from the military solution to a political one (change of a NATO strategy concept). With a decreasing probability of a vast international and global military conflict and, on the other hand, with the increasing industrialisation of the society, affects on the climate and gradual globalisation of the world with all its negative consequences, the field of protection against disasters gains its dominant position within the protection of population.

The mission of protection of population is similar in all compared countries. They usually speak about protection of population and living conditions, protection and salvation of persons "in disasters and emergencies", "special emergencies", "under all conditions", "in peacetime and in case of defence" or "survival of emergencies in any way". Thereof flows that majority of countries focus on protection of population today, especially against natural disasters, technical disasters and emergencies.

The systems of population protection in the compared countries include different components according to their own conception. In particular, the task how to manage daily events, disasters, and emergencies and planning in case of war differ in every country.

Different designation of the systems called protection of population, civil protection, civil defence or civil security does not mean that these are principally different systems. Today, all countries focus on prevention and management of natural disasters, technical disasters and emergencies in the field of protection of population. All countries take measures to protect population in disasters, emergencies and in case of war with sources designed for use in daily events. There are tendencies that the same, especially resolute management of organisational and executive structures is able to secure tasks both in daily events and, having been duly reinforced, in disasters and emergencies or war, as the case might occur. There is also a tendency to achieve the most possible integration of individual rescue entities in daily events.

The differences consist, first of all, in setting tasks to organisations intended for engagement, and in the particularities in measures taken by the individual countries to enforce the resources 
intended for engagement. In Switzerland, Germany and France, second-plan resources are available for engagement in disasters. Armed forces provide subsidiary support in all countries. Neutral states like Switzerland, Finland and Sweden take extensive measures in case of war (including protective infrastructure). Compared to other countries, Sweden and Switzerland take the most extensive measures in the field of protection of population.

\section{Main Tasks}

In daily events the tasks performed by rescue first-plan branches in an integrated system within their professional specification are aimed primarily at salvage of persons and property. Performance of routine tasks does not require extensive planning as a rule and standard routine activities are usually sufficient for coping with tasks successfully.

In case of disasters and emergencies and armed conflicts, in particular, there are a lot of tasks requiring extensive preparation, planning, material resources and finances. The tasks of population protection in an armed conflict (civil protection, civil defence) are specified by Additional Protocols I and II to Geneva Treaties of 1949 , ratified by all countries. However, these protocols cover only armed conflicts. During last twenty years a lot of tasks contained therein were being applied in peacetime during various disasters and emergencies or vice versa, a lot of measures intended for protection of population against disasters and emergencies could be implemented in war after having been enhanced and replenished.

In most European countries, at present, the tasks are as follows:

- Warning and information system

- Principles of behaviour

- Building of protective infrastructure

- Health protection

- Self-protection and mutual aid

- Protection of cultural values

The tasks listed above are the most typical ones for majority of European countries, but specific features exist in almost each country.

In some countries (Germany), warning and information system was split into peacetime and wartime both in terms of competences (the state in case of war and federal lands in peacetime) and technical resources (sirens in peacetime and mass media in wartime); in lot of countries (Sweden, Switzerland, etc), a single organisational and technical system exists for both situations.

The greatest differences are in building of protective infrastructure (Switzerland - 100\% shelter coverage, France - has no shelters and does not build them). This arises especially from financial reasons since this method of population protection requires high budget means.

Protection of cultural values is more declared in some countries (Germany), while in others (e.g. in Switzerland) it is performed both in terms of documentation and implementation (shelters designed for mobile cultural assets).

Some countries (e.g. Austria) pay extraordinary attention, both in the theoretical and practical respect, to protection of population against ionising radiation in peacetime in case of a breakdown in some of nuclear power plants located in the vicinity of Austria.

Other countries (e.g. France) also include tasks related to environmental protection into protection of population, especially in connection with the damage of the environment in case of vast disasters and emergencies.

The other way round, so-called individual chemical protection does not belong among the tasks of population protection in Europe, i.e. protective masks or skin protective equipment supplied from the state resources. This is a relic in post-communistic states, though such means make a part of shelters as equipment for the sheltered in some northern countries (Sweden). The states storing such equipment in large quantities for population try to minimise its number and secure it primarily for children, youth, social sphere, and industrialised and endangered areas (in the vicinity of chemical plants and nuclear power plants in particular). Nothing prevents people from selecting such equipment from a rich commercial offer and from acquiring it at their own cost.

\section{Powers}

Powers in individual fields of activity within protection of population depend on administration structure of a given state. Powers can be generally divided into following levels:

- Central (state, confederate state, federative state)

- Land (federal lands in the states with federal system, cantons)

- Higher middle (regions, provinces, zones)

- Lower middle (districts, departments)

- Municipal (communities, towns, cities)

It generally holds that the smaller "adverse" event in relation to population, the lower administration level is competent and also responsible for its management and vice versa. However, especially in the cities with a four-level or five-level administration structure, this rule does not hold completely and deviations towards higher or lower levels of management appear.

Powers for solving daily events are mostly at the lowest level of management, i.e. municipal self-government (Scandinavian countries, Germany). There is a great difference between a community in the German and Scandinavian conception from the territorial point of view, since due to urbanisation of the landscape, the community cadastral area in Finland or Sweden is many times larger than in Germany and density in a built-up area is in an opposite ratio. In Switzerland and Austria the differences in the powers between communities and cantons or communities and land districts are not so apparent in this field. In France the main centre of gravity of powers is at the level of department in daily events too. 
In case of disasters and emergencies, the powers for their solving and also their prevention always lay on the intermediate level of management. For example: federal lands in the states with federal structure (Germany, Austria), cantons in Switzerland, and departments supported by defence zone in France. Scandinavian countries represent a certain exception where the intermediate level of management is suppressed and communities hold the responsibility with direct support of the state. For example in Sweden, regions play secondary role in this field and they perform their tasks only in case of a breakdown of nuclear power plants. However, in all countries the state plays a supporting and especially a co-ordinating role in vast disasters and emergencies, and events exceeding the borders of federal lands, cantons, departments, etc., or inflicting simultaneously more of the above mentioned territorial units.

The state is always responsible for protection of population in case of war (civil protection, civil defence) regardless the character of an armed conflict. Yet, in peacetime, the state takes a lot of organisational, material, technical, and personnel measures to protect population in case of war depending on concrete conditions (historical, geographical and social ones) and most of all depending on its financial possibilities. The state in some countries (Germany) got rid of some powers in this field in favour of federal lands with the aim to reduce costs which had a negative impact especially after September 11, 2001 in the U.S.A. Currently there has been a tendency to re-enforce the role of the federal state in the field of protection of population in Germany.

\section{Rescue Entities}

Rescue entities within protection of population can be divided as follows:

- First-plan

- Second-plan

- Acting on a subsidiary principle

First-plan resources intended for protection of population are especially fire fighters, health rescue workers, and auxiliary services. Fire fighters are intended to fight against fires, prevent damages, salvage people and provide technical assistance. They participate in rapid health aid and transport of patients in some countries (France, some federal lands in Germany). Fire fighters' department is a member of an ambulance in Scandinavian countries.

Health rescue workers have powers to salvage persons, provide rapid health aid, transport patients and are directly linked to acute bed fund in health facilities.

In German-speaking countries (Germany, Austria), so-called auxiliary services play an important role even within first-level units. To name some of them: the Red Cross, Geneva Rescue Service, Johannite Accident Aid, Operating Samaritan Union and German Society for Life Salvage. They are designated primarily for salvage of lives and health of persons. The Austrian Red Cross is even a decisive first-plan health rescue organisation with a sufficient number of professionals, hardware and transport means. A lot of other profession-oriented organisations as e.g. mountain service (Alpine countries), cave rescue service, organisations with rescue dogs and various charitable and clerical organisations should be associated with the most important ones. Their activities within the area of protection of population is defined by law (e.g. in Germany).

Special units intended for using during disasters and emergencies act as second-plan forces and resources in some countries. In Germany, this is so called Technical Auxiliary Service (hereinafter referred to as the "THW") which is an independent federal institute within the Federal Ministry of Interior with its branches in most of federal lands and with more than 600 bases. The task of these units of different specialisation is, first of all, provision of technical assistance in vast disasters even in abroad. In France, Denmark, and Slovakia, special military units consisting of regular soldiers, and conscripts (executing their service on the basis of Compulsory Service Act) are intended to support the first-plan units to cope with vast disasters. These units are detached from Armed Forces and are responsible to the Ministry of Interior and contain the elements intended for liquidation of natural and anthropogenic disasters. They are also able to provide health aid to victims (engineer troops, fire-fighting units, chemical units and health units). In Switzerland persons subjected to compulsory service in civil protection, regularly educated and trained, are designed for this activity. The Switzerland legislation makes possible, within devolved power that the city mayors may call out such persons to cope with natural and anthropogenic disasters within the civil protection field.

In most countries, there has been a current tendency to integrate especially the first-plan units into integrated rescue systems under common management.

\section{Management structures at a state level}

Engagement of rescue units in daily events usually does not require any extensive planning and material measures. Operative routine of individual integrated first-plan units designed for coping with these events is sufficient.

Protection of population during disasters and emergencies, especially in war, requires extensive planning, material, financial and personnel preparation. As a rule, all these activities are secured from the top administrative levels of the given state(land level, state level). Individual professional activities are within the powers of the individual government departments; within the government department of interior or an armed forces structure, the resolute structures for these purposes are built and usually dispose of total control and have a co-ordinating role.

In the states with a typical federalist principle of management and administrative structure(Germany, Austria, Switzerland), final responsibility for protection of population during disasters and emergencies lays on federal lands (Germany, Austria) and cantons (Switzerland) according to a respective land (canton) legislation. 
Respective resolute management structures were built for this purpose on the level of land ministries of interior and canton administration. If disasters or emergencies are so vast that they inflict several federal lands and more cantons, and if the war begins, protection of population (usually civil protection in war) is within the power of the state. Resolute organisational and management structures are built for this purpose on the state level. (Civil Protection Department of the Federal Administration Office of the Federal Ministry of Interior in Germany, Civil Protection Department of the Federal Ministry of Interior in Austria, Federal Civil Protection Office of the Ministry of Defence, Protection of Population and Sport in Switzerland).

In countries with a centralised structure (Scandinavian countries, France, etc.), the final responsibility for protection of population in disasters and emergencies and in war (civil protection) is on the resolute structures built for this purpose by the government department of interior or defence as a rule: Rescue Department of the Ministry of Interior in Finland, Civil Readiness Office and Rescue Services Office of the Ministry of Defence in Sweden, Office for Management under Threat of the Ministry of Interior in Denmark, Directorate of Defence and Civil Security of the Ministry of Interior in France. Within these resolute structures there are also second-plan rescue units with nation-wide competence in some countries (Denmark, France).

To secure the tasks of civil protection or defence (protection of population in war), the above mentioned central management structures are additionally staffed so as to cope with all planned tasks in case of a war conflict. Their activity is usually supported by flexible structures (various inter-government department advisory, information and co-ordination committees consisting of representatives of various involved ministries).

\section{Service Model}

Service in rescue units within the area of protection of population is based on:

- Service obligation - implemented on so called service days (hereinafter referred to as the service days)

- Voluntarism - implemented on service days without financial or legal stimulation

- Professionalism - implemented by service days paid by the market price

"Pure" model of service does not practically exist in rescue units in individual European countries; there is always a prevailing part of one of the above listed forms.

Extensive service obligation (militia system) is used mainly in Switzerland with cc $75 \%$ of fire fighters and $100 \%$ members of civil protection organisations as a second-plan element of engagement. In France there are Military rescue units (UIISC) with a nation-wide power acting on the basis of service obligation. In Denmark there are regional bases of the National Rescue Corps and the Slovak Republic disposes of Civil Protection Rescue
Brigades of the Civil Protection Office at the Ministry of Interior of the Slovak Republic.

The principle of voluntarism is applied mainly in Germany and Austria where the fire fighters and auxiliary services or rescue organisations are organised almost exclusively on the basis of voluntarism. This principle is enforced partly by the fact that the fire fighters in both countries must create part of their financial charges by their own means, and it further results from historical traditions consisting in positive attitude of population towards federal and denominational activities. Professional fire fighters act mainly in large cities in both countries. The already mentioned organisation THW in Germany acts on the basis of volunteers (except for a necessary number of managers). It fulfils a function of nationwide second-plan resources and is engaged in case of vast natural and anthropogenic disasters even abroad.

In Scandinavian states especially in Finland and Sweden rescue services (fire fighters have no legal subjectivity, but they are a segment of rescue service) are mostly based on a professional basis. These services cover a wide range of tasks, especially in the cities. Voluntary health rescue services support rescue services mainly in the country where rescue services consist mostly of part-time workers or volunteers (especially in Finland).

Some units are replenished by staff on the basis of civil or substitute service. These units are mainly the THW units in Germany, auxiliary services in Austria and rescue services in Sweden. Their number is low (several thousand of persons).

Each of the mentioned models has its advantages and disadvantages. Militia system in such a large extent as practised in Switzerland requires education and training of persons subject to compulsory service and it also requires off-budget costs. A professional model guarantees a certain standard on professional level; however, it requires extensive budget costs. Certain optimum seems to be a combination of all three models of service respecting specific conditions and cultural-historical traditions of a given state.

In some countries (e.g. France), there is an effort to increase the portion of professionals, especially with fire fighters like in Scandinavian countries; in other countries (Austria, Germany) principle of voluntarism has been still maintained.

\section{Education and Training}

Education process including practical training and joint exercises of individual rescue units of protection of population depends primarily on the model of the service and also on the character and specificity of each rescue entity.

In case when the model is based on compulsory service (militia system), which is most extensively used only in Switzerland and in a limited extent in France, and Sweden, great demands are posed upon educational and training facilities. Education and training of e.g. 160 thousand fire fighters within the canton compulsory 
service and 300 thousand members of civil protection organisations within the national compulsory service in Switzerland require a great number of educational facilities (roughly one in each canton), lecturers, auxiliary staff, and budget finances.

A professional model with regard to a limited number of professional rescue entities poses claims primarily on a high level of educational facilities, professional quality of lecturers, material and technical equipment, and training premises.

Volunteers in rescue entities are mostly prepared for their service on the lowest administrative and self-government level (besides nucleus of commanders) within their related organisation.

Basic education of fire fighters is performed mostly in communities (Switzerland, Germany) and departments (France). Further special education and education of nucleus of commanders is performed on canton level (Switzerland), federal lands (Germany, Austria) or in the central educational facility (France). In countries where fire fighters make a segment of so-called rescue service (Finland, Sweden), education is provided in central educational facilities on state level.

Members of health rescue service and police are prepared for tasks in protection of population mostly in their own government department facilities within their professional training.

Auxiliary services and other organisations of various legal nature providing assistance to the first-plan units (primarily in the German-speaking countries) are mostly trained in their own facilities; Their nucleus of commanders also takes part in training in central facilities on state level.

Second-plan units designed for engagement in disasters and emergencies (UIISC in France, THW in Germany, National Rescue Corps in Demark) are trained in central educational facilities on state level. A certain exception represents the THW in Germany with cc 70 thousand members educated and trained at the level of community and managers educated and trained at the level of a federal state.

Units of armed forces intended to provide subsidiary assistance, mostly in the countries where the second-plan resources of engagement do not exist. In this case the country does not perform any special education and training within the area of protection of population.

Most countries tend to perform educational processes jointly with the aim at optimisation in the engagement itself. There is a trend asserted to perform the basic and further education of the members of rescue units centrally in one or few educational facilities.

\section{Protective Infrastructure (protection provided by shelters)}

Essential part of protection of population is so-called protective infrastructure comprising shelters for population, protected facili- ties (health facilities, communication equipment, warehouses) and protective constructions (command posts, dispatcher posts, etc.).

Building of protective infrastructure is a long-term process, finances-intensive and it is closely connected with the concepts of population protection as a whole. Protection of population in shelters has served almost exclusively in case of an armed conflict, which can theoretically arise in a relatively short period of time. If the shelters are in good technical conditions and in full operating conditions, usual time to get them ready for operation takes cc 24 hours. From these reasons as well as the reasons of dislocation, these shelters cannot be used immediately for protection of population in natural and anthropogenic disasters or in case of an unexpected terrorist attack.

Long-term attention was paid to the problems related to building of protective infrastructure mainly in Switzerland, Scandinavian countries, and Israel where percentage of protection of population in shelters in comparison with the number of population is very high. Protective infrastructure has been built in these countries after World War II for more than 50 years and necessary legislation conditions have been created for these activities. The basis of them comprised individual acts specifying building of shelters in defined kinds of structures, as e.g. Federal act on building measures in civil protection of 1963 as amended (Switzerland).

The level of shelters provided for protection of population in relation to the number of inhabitants varies in different countries. Though different standards for shelter division into categories are applied especially from the pressure resistance at the front of a overpressure wave and equipment availability point of view, certain comparisons can be made. The highest level shows Switzerland 95-100 \% (in relation to the number of inhabitants, however it shows local gaps and "exceeds") and Sweden - approximately 80 $\%$. Next is Finland - approximately $50 \%$ (70 \% in the south, $40 \%$ in the north) and Austria - approximately $30 \%$ (great differences are among individual federal lands - Styria $70 \%$, Vienna $3 \%$, and great differences are in equipment and usability). On the other hand, Germany shows shelters only for $3 \%$ of inhabitants (after World War II no shelters have been built) and in France where no shelters for the population are available. The existing fund of shelters has merely been maintained in all European countries, only in Finland building of shelters has been continuing with the aim to provide protection in fixed, pressure-resistant shelters for as much people as possible.

Most of already built or currently built public shelters are shelters built from public finances and they are called double-use structures because of being used as hostels, garages, etc. in peacetime and serving to its original purpose - protection of population after getting to operating conditions.

\section{Co-operation with Armed Forces}

Armed forces provide subsidiary support during disasters and emergencies in all countries. Switzerland Armed Forces dispose 
of a department for assistance during disasters (cc 2.4 thousand members) and rescue units (cc 23 thousand members) divided into groups specialised for these purposes. Other countries also have groups within armed forces, which can be engaged in assistance both inside and outside the state. These groups usually dispose of heavy mechanisms, instruments and transport means. The principle that armed forces are asked for assistance if the civil resources are insufficient to cope with the event is applied in all countries. Corresponding conditions or deadlines are not defined by any key decrees. The most significant support of armed forces is provided in France where, together with special military units of the Ministry of Interior (UIISC), groups for assistance during disasters are available permanently. In Austria, armed forces may be asked anytime for intervention by relevant political bodies. In Germany, armed forces are used mainly in the field of health rescue service.

Assistance from the part of armed forces is mostly preceded by respective planning activity at all levels of state administration and self-government. This assistance has a decisive meaning for the states lacking nation-wide (second-plan) forces and means to cope with disasters and emergencies. Optimal co-operation between civil and military sphere is in the countries where ministry of defence is a warrantor responsible for co-ordination and control of civil emergency planning (Sweden, Switzerland). This is expressed under "normal" situation mostly in a joint planning activity for emergencies, usually based on the co-ordination contracts, and in performance of joint training and practical co-ordination exercises.

\section{International Co-operation}

Actions abroad within international assistance in disasters and humanitarian aid play more important role in most countries. Principally this means the second-plan resources of engagement and a lot of countries have been establishing special units for these purposes (SEBA within the THW - Germany, FINNENRESCUEFORCE - Finland, etc.). Logistic support of these units makes possible to transport these units including their material and equipment to any place of engagement.

\section{Research Support of Population Protection in the Czech Republic}

Research and development in advanced democratic states are being evaluated as a decisive factor of the society level, and a decisive factor of its further progress. The base for the successful orientation of individual areas of science and research are working systems of management, especially their rational supreme bodies and institutions for scientific and information support. Current development in the field of science and research is impossible without versatile co-operation and integration.

In December 2003 the European Union Council Resolution on strengthening community cooperation in the field of civil protection research was adopted $(2003 / \mathrm{C} 8 / 2)$.
Consequently in 2004 the European Union established preliminary research program in the security field for years $2004-2006$ including population protection against CBRN issues, emergency management and warning of population.

As well as the NATO opens Program for Security through Research. Prior areas are: CBRN detection, population protection against CBRN, decontamination and protection of critical infrastructure sections.

Current and long-term research program in the Czech Republic is complying with the above stated matters and is being preferably oriented to strategic ways including especially:

- warning of population

- analysis, detection and decontamination of highly toxic substances including CBRN

- emergency management

- personal means of population protection

- communication and information systems

In the area of timely warning of population the research is aimed at a multidiscipline approach of task solving and integration of the outputs with other expertnesses such as emergency management, protection of population, informatics, and communication. The products after further elaboration will be used in an education process for preparation of emergency management, users of a unified system of warning, and a groundwork for concept materials, materials for decision making support of leaders etc.

In the area of analysis, detection and decontamination of highly toxic substances the development of chemical research and laboratory verification is being insured. The activities encompass the development of methodology and means of detection, characterization, identification and determination of highly toxic substances including CBRN issues in case of their rampant leakage into the environment as a result of a breakdown or a terrorist misuse, and interpretation of measured data oriented to mitigation or elimination of leakage consequences for population.

In the area of emergency management it appears indispensable to create conditions for a coordination and controlling role of an emergency control by means of practical tools of an emergency manager in the stage of the preparation for an emergency, in the stage of still manageable emergencies, in the stage of coping with emergencies, and finally in the phase of liquidation of consequences and sanitation works. This presupposes especially further research of methodology of risk analyses for emergency preparedness in the frame of planning of emergencies and crisis situations on the territory. In further research it is necessary to continue on elaboration of methodology designed for mastering of decision making processes in crisis staffs with the support of information and communication technologies. Attention to the role of working with the public on all levels of control is also paid.

In the area of personal means of population protection it will be necessary to develop the testing of personal protective equipment 
( PPE). The aim is, on the base of acquired results of PPE testing, to suggest measures for lengthening of their operation lives. Attention is also paid to the issue of improvised shelters that should fill up the current shelter fund in the Czech Republic.

In the area of communication and information systems it is necessary to create adequate conditions for the development and realization of these systems as an efficient support in connection with operation processes, linked with the preparation for solving, and final solving of emergencies and crisis situations. In this context it means control processes imminently touching all central administration authorities, other administration bodies, self-administration bodies, and in the final eventuality all citizens of the Czech Republic. Information and communication systems for the support of emergency control have to therefore, among others, make possible to hold independent communication channels by means of reserve nets during the crisis, manage the course of crisis situations from different places including air means, use up-to-date relevant data wherever accepted, whenever, and in whatever way and manage the course of a crisis situation or currently proceeding emergencies in a group and not only individually. In the frame of these systems the emphasis will be placed on the mutual interconnection of function sections strengthening especially an up-to-dated integrated picture of the situation, a tool for evaluation of the magnitude of the situation, visualization of information, operation planning. Further the emphasis will be placed on the possibility of command and control of intervention units and monitoring of their activities in the terrain, shortening of the time necessary for the performance of orders and control directions, tools for debriefings and realization of training.

In conclusion it is possible to claim that on the base of new threats appearing lately, especially terrorism, the research activity in the area of population protection and emergency management becomes utterly indispensable and not substitutable.

\section{References}

[1] Security of Cooperation (in German), The report of federal council on safety policy of Switzerland from 7. June 1999 proposed at federal congress, Bern 1999.

[2] Swiss General Risk-Analysis (in German), Bern 1999.

[3] Common Security and the Future of the Army (in German), The report of Weizsäcker's committee for federal government, 2000.

[4] International CEP Handbook 2003: Civil Emergency Planning in the NATO/EAPC Countries, SEMA, Stockholm 2003.

[5] Defense and Civil Security - Everybody's Affair (in French), The booklet of civil safety directorate, Paris 2000.

[6] Robustness in the Physical Environment, The Swedish Agency for Civil Emergency Planning and the Swedish Board of Housing, Building and Planning in co-operation with the Swedish Rescue Services Agency and the Swedish Environmental Protection Board, Stockholm 1999.

[7] Main Idea of Population Protection (in German), Government report for the parliament on the population protection conception), Bern 2001.

[8] International Directory 2001 - Civil Protection, Civil Defence, Civil Safety, Emergency Management, International Civil Defence Organization (ICDO), Geneva 2001.

[9] Procedural methods for the support of decision making in favor of crisis management the project of defensive research under the code PROCES, Research project, ICO ČR, Lázně Bohdaneč 1999.

[10] The conception of population protection until 2006 with prospects till 2015, MV-Ǧ̌ HZS ČR, Praha 2003. 